\title{
VALSTS VARAS ORGĀNU APKALPOJOŠĀS IESTĀDES
}

\section{SUPPORTING AUTHORITIES FOR STATE ORGANS}

\author{
Jānis Priekulis, $M g$. iur. \\ Latvijas Universitātes Juridiskās fakultātes doktorants
}

\section{Summary}

According to the Constitution of the Republic of Latvia (Satversme), there are seven organs, through which Latvia acts - all Latvian citizens together, the Parliament, the President, the Cabinet of Ministers, the courts, the Constitutional Court and State Audit Office. In this article, the author analyses the authorities that are established in order to support these organs - facilitate the execution of their functions according to the Constitution and deal with certain administrative matters.

Atslēgvārdi: valsts varas orgāns, apkalpojošā iestāde, valsts, Satversmes tiesas kanceleja, Augstākās tiesas administrācija

Keywords: a state organ, a service authority, state, the chancellery of the Constitutional Court of Latvia, the administration of the Supreme Court of Latvia

\section{Ievads}

Latvijas valsts kompetence ir sadalìta starp valsts varas orgāniem. Satversme noteic, ka ir septiņi valsts varas orgāni - Latvijas pilsoṇu kopums, Saeima, Valsts prezidents, Ministru kabinets, tiesas, Satversmes tiesa un Valsts kontrole. Tas ir izsmel̦ošs uzskaitījums. Nevar būt valsts kompetences, kas nav piešķirta kādam valsts varas orgānam. To ir atzinusi arī Satversmes tiesa. ${ }^{1}$

Teorija par valsts varas orgāniem ir plaši atzīta Latvijas tiesību dogmatikā, taču tikai nesen tiesību doktrīnā ir īpaši izdalīta atsevišķa valsts iestāžu grupa, ${ }^{2}$ ko veido iestādes, kuras apkalpo valsts varas orgānus, piemēram, Valsts prezidenta

1 Raksta autors ir Jānis Priekulis, Latvijas Universitātes Juridiskās fakultātes doktorants. Rakstā sniegts autora personīgais viedoklis, un tas nav saistošs vai saistīts ne ar vienu institūciju, kurā autors strādā vai citādi darbojas.

Sk.: Satversmes tiesas 20.12.2006. spriedums lietā Nr. 2006-12-01, 6.2. punkts. Satversmes tiesas spriedumā lietots jēdziens "valsts varas konstitucionālā institūcija", bet šajā rakstā lietots jēedziens, kuru izmantojis arī Kārlis Dišlers, proti, "valsts varas orgāns”. K. Dišlers līdztekus šim jēdzienam izmantoja arī jēdzienu "valsts orgāns”. Piemēram, sk.: Dišlers K. Latvijas valsts orgāni un viṇu funkcijas (turpinājums). Tieslietu Ministrijas Vēstnesis, 01.11.1924., Nr. 11.

2 Piemēram, sk.: Briede J., Danovskis E., Koval̦evska A. Administratīvās tiesības. Mācību grāmata. Rīga: Tiesu namu aǵentūra, 2016, 50.-51. lpp.; Danovskis E., Briede J. Satversmes 58. panta komentārs. Grām.: Autoru kolektīvs. Latvijas Republikas Satversmes IV nodaḷas komentāri. Rīga: Latvijas Vēstnesis, 2017, 557. lpp. 
kanceleja, Saeimas administrācija un Satversmes tiesas kanceleja. Tas ir arī viens no iemesliem, kāpēc līdz šim ir izveidojies fragmentārs šo iestāžu normatīvais regulējums un trūkst sistēmiska redzējuma par to statusu un lomu valsts varas ìstenošanā.

Raksta mērķis ir aplūkot iestādes, kuras apkalpo Latvijas valsts varas orgānus, skaidrojot, kuras ir šìs iestādes, kam tās vispār ir nepieciešamas, kāda ir to kompetence, kāds normatīvais regulējums tām ir piemērojams, kā tās nošķirt no citām iestādēm un kāpēc šādas iestādes nevar uzskatīt par valsts varas orgānu struktūrvienībām.

\section{Valsts varas orgāna jēdziens un izpratne}

Kārlis Dišlers savā grāmatā "Valsts varas orgāni un viṇu funkcijas” raksta, ka valsts orgāna nosaukums radies organiskās valsts teorijas izplatīšanās laikā, un pēc šìs teorijas valsts ir sociāls organisms, kas daudzējādā ziṇā līdzịgs biologiskam organismam. ${ }^{3}$ Tāpat kā biologiskā organismā pastāv savstarpēja sakarība starp organismu un viṇa orgāniem (viens bez otra nav iedomājami), tāpat arī valsts nav iedomājama bez saviem orgāniem. Valsts darbojas tikai caur saviem orgāniem, un bez saviem orgāniem nav juridiski spējīga. ${ }^{4}$

Visi valsts varas orgāni, izṇemot Valsts prezidentu, ir koleg̣iāli vai koleǵiāli vadīti. Pilsoṇu kopums sastāv no Latvijas pilsoņiem, Saeima - no 100 tautas priekšstāvjiem (Satversmes 5. pants), Satversmes tiesa - no septiṇiem tiesnešiem (Satversmes tiesas likuma 3. pants), Ministru kabinets - no Ministru prezidenta un ministriem (Ministru kabineta iekārtas likuma 5. pants), Valsts kontrole ir koleǵiāli vadìta iestāde, ${ }^{5}$ bet tiesas ir koleǵiāls orgāns, un tas izriet no Satversmes 83. panta vārdiem “Tiesneši ir", 84. panta vārdiem "Tiesnešus apstiprina” un arī no realitātes - Latvijā ir vairāki tiesneši, nevis tikai viens.

Augstākā tiesa nav atseviškss valsts varas orgāns. Latvijā bez Augstākās tiesas ir arī citas tiesas, kuras spriež tiesu, un tās nav Augstākās tiesas sastāvā. Arī Kārlis Dišlers grāmatā "Valsts varas orgāni un viṇu funkcijas" par valsts varas orgānu uzskata tiesas kopumā, nevis atsevišķu tiesu. ${ }^{6}$

Valsts varas orgāna sastāvā esošās personas var izveidot dažādus iekšējus organizatoriskus veidojumus, piemēram, Satversmes tiesas tiesneši var izveidot kolēgijas pieteikumu izskatǐšanai, Saeimas deputāti - Saeimas prezidiju, Frakciju padomi, komisijas, frakcijas, vai tiesneši - Tiesnešu ētikas komisiju, Tiesnešu disciplinārkolēgiju, Disciplinārtiesu vai tiesnešu konferenci. Ir raksturīgi, ka šādu iekšéjo organizatorisko veidojumu kompetenci nosaka likumā.

Visa valsts vara - likumdošanas vara, izpildvara un tiesu vara - ir sadalīta starp valsts varas orgāniem. Tas gan nav saprotams tā, ka kādu no valsts varām ekskluzīvi īstenotu viens valsts varas orgāns. Piemēram, lai arī atbilstoši Satversmei likumdošanas varu galvenokārt īsteno Saeima, bez Saeimas to ìsteno arì pilsoṇu kopums. Tāpat, lai arī saskaṇā ar Satversmi izpildvaru galvenokārt īsteno

3 Sk.: Dišlers K. 1924, 456. lpp.

4 Par to, ka valsts var darboties caur saviem orgāniem, sk.: ibid., 457. lpp.

Par Valsts kontroli un tās apkalpojošās iestādes neesību plašāk sk. raksta turpinājumā.

6 Sk.: Dišlers K. 1924, 458., 462. lpp. Tolaik bija Senāts, ne Augstākā tiesa, bet arī Senātu nedēvēja par valsts orgānu. 
Ministru kabinets, bez Ministru kabineta to īsteno arī Valsts kontrole un Valsts prezidents. $^{7}$

Lai apzīmētu Latvijas pilsoṇu kopumu, Saeimu, Valsts prezidentu, Ministru kabinetu, tiesas, Satversmes tiesu un Valsts kontroli, jēdziena "valsts varas orgāns" vietā var lietot arī citus jēdzienus, piemēram, "valsts orgāns", "konstitucionāls orgāns", "konstitucionāla institūcija" vai "Latvijas konstitūts". Jāpiemin, ka Latvijas Zinātṇu akadēmijas Terminoloǵijas komisija 2002. gadā ierosināja vārda "orgāns" vietā lietot vārdu "konstitūts". Tika skaidrots, ka tas ir jaundarinājums latviešu valodā un konstitutivs ir tāds veidojums, kuru tiesiski izveido līdz ar pašu juridisko personu, bez kura juridiskā persona nevar pilnvērtīgi tiesiski darboties (tā nav rīcībspējīga) un kura maiņa vai likvidācija maina juridiskās personas būtību. Vārds "orgāns" noderot neoficiālā vai tēlainā raksturojumā, bet neiederoties zinātniski un teorētiski pamatotas nozares terminu sistēmā un normatīvajos aktos, jo oficiālajai terminologijai esot raksturīga stilistiska neitralitāte, kā šim vārdam trūkst. ${ }^{8}$

Respektējot Latvijas Zinātņu akadēmijas Terminologiijas komisijas lemto, jāṇem vērā, ka vārds "konstitūts" šo padsmit gadu laikā pēc komisijas lēmuma tikpat kā netiek izmantots, arī normatīvajos aktos ne. Tādēl Latvijas pilsoṇu kopums, Saeima, Valsts prezidents, Ministru kabinets, tiesas, Satversmes tiesa un Valsts kontrole šajā rakstā apzīmēti ar Latvijā pierastāku jēdzienu, tas ir, "valsts varas orgāns". Vārds "orgāns" tiek lietots normatīvajos aktos, ${ }^{9}$ tostarp arī Satversmē. ${ }^{10}$ Jēdzienus “valsts varas orgāns” un "valsts orgāns” ir izmantojis arī Kārlis Dišlers. ${ }^{11}$

\section{Valsts varas orgāna apkalpojošās iestādes nepieciešamība}

Ja Latvijas valsts nespēj darboties bez saviem orgāniem, tad valsts varas orgāns nespēj efektīvi īstenot tam uzticētās funkcijas bez apkalpojošās iestādes. Valsts varas orgāna apkalpojošā iestāde rada priekšnoteikumus attiecīgā valsts varas orgāna darbībai, palīdzot tam īstenot tā funkcijas Satversmes un likumu robežās, kā arī risināt dažādus administratīva rakstura jautājumus. Vienlaikus valsts varas orgāna apkalpojošās iestādes esība ir attaisnojama tikai ar paša valsts varas orgāna esību, un tai nav savu, no valsts varas orgāna atšķirīgu funkciju - tās mērḳis ir kalpot valsts varas orgānam. Tas nozīmēe ja valsts varas orgāns vairs nepastāv, izbeidzas arī valsts varas orgāna apkalpojošās iestādes vajadzība, un otrādi - izveidojot jaunu valsts varas orgānu, rodas vajadzība pēc jaunas apkalpojošās iestādes.

Saeima kā kolegiāla institūcija galvenokārt īsteno likumdošanas varas funkciju, un tā nav iedomājama bez tādiem darbiem kā priekšlikumu apkopošana, tabulu gatavošana Saeimas un komisiju sēdēm, Saeimas un komisiju sēžu protokolu

7 Tādēl varas dalīšanas princips tiek saprasts gan institucionāli, gan funkcionāli. Plašāk sk.: Konstitucionālo tiesību komisijas 2011. gada 10. maija Viedoklis par Valsts prezidenta funkcijām Latvijas parlamentārās demokrātijas sistēmas ietvaros, 13. lpp. Pieejams: http://blogi.lu.lv/tzpi/ files/2016/12/KTK_VP_FUNKCIJAS.pdf [aplūkots 13.01.2019.].

${ }^{8}$ Sk.: Latvijas Zinātņu akadēmijas Terminologijas komisijas 31.05.2002. lēmumu Nr. 14, protokols Nr. 4/1028. Latvijas Vēstnesis, 05.06.2002., Nr. 84 (2659).

9 Vārdu "orgāns" lieto arī normatīvajos aktos. Piemēram, sk. Valsts pārvaldes iekārtas likuma 1. panta 4. punktu un 29. pantu.

10 Atbilstoši Satversmes 86. panta pirmajam teikumam tiesu var spriest tikai tie orgāni, kuriem šīs tiesības piešḳir likums, un tikai likumā paredzētā kārtībā

11 Piemēram, sk.: Dišlers K. 1924. 
rakstīšana, arī bez izvērtējuma, vai likumprojekts un priekšlikumi ir noformēti atbilstoši juridiskās tehnikas prasībām un vai tajos ietvertās normas atbilst augstāka juridiskā spēka tiesību normām. Tāpat Saeimai vajadzīgs risināt dažādus administratīva rakstura jautājumus, piemēram, uzturēt Saeimas ēku un kārtot grāmatvedỉbu. Šo darbu veikšanai tiek izveidota īpaša iestāde. Saeimai tā ir Saeimas administrācija, kura minēta arī Saeimas kārtības rullīin ${ }^{12}$ un kuras nolikums precīzi atspoguḷo tās kā apkalpojošās iestādes mērḳi - nodrošināt visu nepieciešamo atbalstu Saeimas funkciju izpildei un Saeimas deputātiem, lai viṇi varētu īstenot Satversmē, Saeimas kārtības rullī un citos normatīvajos aktos noteiktās pilnvaras. ${ }^{13}$

Saeimas administrācijā ir vairākas struktūrvienības, kuras laika gaitā var mainīties. Pašlaik tās ir, piemēram, Finanšu nodaḷa, Saimnieciskā nodrošinājuma nodaḷa, Autobāze, Juridiskā atbalsta nodaḷa, Personāla nodaḷa, Dokumentu pārvaldỉbas nodaḷa, Protokola nodaḷa, Saeimas drošỉbas birojs, Tehnikas nodaḷa, Saeimas sēžu nodrošinājuma nodaḷa, un kopumā Saeimas administrācijā strādā daži simti darbinieku. Tas ir liels skaits cilvēku, un Saeimas administrācijā strādā vairāk cilvēku nekā lielā daḷā valsts pārvaldes iestāžu.

Tāpat ir arī ar citiem valsts varas orgāniem, piemēram, Satversmes tiesas apkalpojošā iestāde ir Satversmes tiesas kanceleja, kura gādā par Satversmes tiesas ēkas uzturēšanu, informācijas apriti Satversmes tiesā un citiem darbiem. ${ }^{14}$ Augstākajai tiesai tā ir Augstākās tiesas administrācija, kura organizē un nodrošina tiesas administratīvo darbu - veic finanšu vadību, gādā par materiāltehnisko nodrošinājumu, kārto lietvedību, organizē personālvadību un apmācības, nodrošina saziṇu ar sabiedrību un veic starptautisko sadarbību. ${ }^{15}$ Ministru kabinetam tā ir Valsts kanceleja, kuras nolikums precīzi atspoguḷo tās kā apkalpojošās iestādes mērksi - radīt priekšnoteikumus Ministru prezidenta, Ministru prezidenta biedra un Ministru kabineta darbībai, lai nodrošinātu lēmumu pieṇemšanu saskaṇā ar Satversmi un citiem likumiem, kā arī Ministru kabineta lēmumu īstenošanu un pēctecību. ${ }^{16}$ Valsts prezidentam, savukārt, tā ir Valsts prezidenta kanceleja, un arī likumā "Par valsts prezidenta darbības nodrošināšanu" ir precīzi atspoguḷots tās kā apkalpojošās iestādes mērḳis - kārtot ar amatā esošā Valsts prezidenta darbību saistītās lietas un pārzināt Valsts prezidenta lietvedību. ${ }^{17}$ Valsts prezidenta kancelejas nolikums precizē kancelejas uzdevumus, piemēram, sagatavot Saeimā pieņemto likumu izsludināšanu un likumu izsludināšanas apturēšanu Satversmē un citos normatīvajos aktos noteiktajā kārtībā, sagatavot un iesniegt Valsts prezidentam nepieciešamo informāciju attiecībā uz likumu otrreizējas caurlūkošanas lūgumiem, nodrošināt likumu atgriešanu Saeimā otrreizējai caurlūkošanai un koordinēt Valsts prezidenta likumdošanas iniciativu priekšlikumu izstrādi un nodrošināt to iesniegšanu Saeimā. ${ }^{18}$

\footnotetext{
12 Piemēram, sk. Saeimas kārtības ruḷ̦a 9. un 22. pantu. Rakstā autors nepievēršas Saeimas biroju un dienestu statusam.

13 Sk. Saeimas administrācijas nolikuma 1. punktu. Apstiprināts ar Saeimas Prezidija 27.03.2017. lēmumu "Par Saeimas Administrācijas nolikuma apstiprināšanu”. Pieejams Saeimā, nav publicēts.

14 Par Satversmes tiesas kancelejas funkcijām plašāk sk. Satversmes tiesas reglamentu, piemēram, 14. 15. un 19. pantu.

15 Sk. likuma "Par tiesu varu" $50 .{ }^{1}$ panta pirmo un trešo dal̦u.

16 Sk. Ministru kabineta 20.05.2003. noteikumu Nr. 263 “Valsts kancelejas nolikums” 1. punktu.

17 Sk. likuma "Par valsts prezidenta darbības nodrošināšanu" 5. panta pirmo daḷu.

18 Plašāk sk. Valsts prezidenta kancelejas nolikumu. Pieejams: https://www.president.lv/lv/kontakti/ valsts-prezidenta-kanceleja/nolikums [aplūkots 13.01.2019.].
} 
Latvijā ir izveidotas šādas valsts varas orgānu apkalpojošās iestādes:

- Saeimas administrācija (Saeimai);

- Valsts prezidenta kanceleja (Valsts prezidentam);

- Valsts kanceleja (Ministru kabinetam);

- Augstākās tiesas administrācija un Tiesu administrācija (tiesām);

- Satversmes tiesas kanceleja (Satversmes tiesai).

Par Valsts kontroli un tās apkalpojošās iestādes esību vai neesību norādāms, ka atbilstoši Satversmei Valsts kontrole ir koleǵiāli vadìta iestāde ar vairākiem valsts kontrolieriem. ${ }^{19}$ Lai arī Valsts kontroles likums paredz vienu valsts kontrolieri Valsts kontroles padomes priekšsēdētāju, Satversmes 87. un 88. panta izpratnē par valsts kontrolieriem ir uzskatāmi visi Valsts kontroles padomes locekḷi. ${ }^{20}$ Tajā pašā laikā pēc iekšējās uzbūves Valsts kontrole līdzinās parastai pārvaldes iestādei, kuru pārstāv un kuras darbu vada Valsts kontroles padomes priekšsēdētājs. Proti, atbilstoši Valsts kontroles likuma 6. pantam Valsts kontroles sastāvā ir valsts kontrolieris, Valsts kontroles padome, Valsts kontroles revizijas departamenti un atbalsta struktūrvienības. Tāpat Valsts kontroles likums nodala Valsts kontroles padomes un Valsts kontroles revīziju departamentu kompetenci, nosakot, ka revīziju departamentiem ir patstāvīgas funkcijas. ${ }^{21}$ Tas nav iedomājams citu valsts varas orgānu gadījumā, jo pastāvīgas funkcijas ir tikai valsts varas orgānam, un apkalpojošā iestāde palīdz tās īstenot. Tādēḷ Valsts kontrole ir koleǵiāli vadīts orgāns, kuram nav atsevišḳas apkalpojošās iestādes, un tas Valsts kontroli atšķir no citiem valsts varas orgāniem.

\section{Valsts varas orgāna apkalpojošās iestādes izveidošana un statuss}

Valsts varas orgāna apkalpojošo iestādi primāri izveido pats valsts varas orgāns, pieṇemot attiecīgu lēmumu. Piemēram, Augstākās tiesas administrāciju izveidoja ar Augstākās tiesas priekšsēdētāja rīkojumu, apvienojot tiesas kanceleju, informātikas, finanšu un saimniecības nodaļu. ${ }^{22}$ Tikai pēc tam Augstākās tiesas administrāciju ierakstīja likumā "Par tiesu varu". ${ }^{23}$ Tas nozīmē, ka valsts varas orgāna apkalpojošās iestādes izveidošanai nav obligāti vajadzīgs likums, un tas izriet no nepieciešamības nodrošināt valsts varas orgāna funkciju efektīvu izpildi. Turklāt tas, ka valsts varas orgāns pats var izveidot savu apkalpojošo iestādi, nozīmē arī, ka valsts varas orgāna apkalpojošās iestādes kompetence var būt ne tikai likumā, bet arī attiecīgā valsts varas orgāna iekšējā normatīvajā aktā, jo ne katram valsts varas orgānam ir piešḳirtas tiesības izdot ārējus normatīvus aktus. ${ }^{24}$

19 Sk. Satversmes 87. un 88. pantu.

${ }^{20}$ Plašāk par to sk.: Saeimas Juridiskā biroja dokumenti. 1993-2013. Rīga: Latvijas Vēstnesis, 2013, 588. lpp.

${ }^{21}$ Piemēram, Valsts kontroles likuma 13. pants noteic: "Revīzijas darbus ar Valsts kontroles padomes lēmumu sadala starp Valsts kontroles revīzijas departamentiem.” Plašāk sk. Valsts kontroles likuma IV nodalı "Revīzijas departamenti".

22 Sk. Augstākās tiesas 29.04.2005. vēstuli Nr. 7-2/1-324 "Par grozījumiem likumā "Par tiesu varu”". Pieejama Saeimas arhīvā pie likumprojekta Nr. 1134/Lp8 "Grozijumi likumā "Par tiesu varu”", nav publicēta.

23 Sk.: Grozījumu likumā "Par tiesu varu” 13. pants. Latvijas Vēstnesis, 07.10.2005., Nr. 160 (3318).

24 Piemēram, atbilstoši likuma "Par valsts prezidenta darbības nodrošināšanu" 5. panta ceturtajai daḷai Valsts prezidenta kancelejas struktūru un iekšējās darbības noteikumus reglamentē nolikums, kuru apstiprina Valsts prezidents. 
Lai nodrošinātu valsts varas orgāna neatkarību un nepārkāptu varas dalīšanas principu, valsts varas orgāna apkalpojošā iestāde nevar atrasties cita valsts varas orgāna padotībā. Valsts varas orgāna apkalpojošā iestāde var būt padota tikai tam valsts varas orgānam, kuru šì iestāde apkalpo. Piemēram, ja Saeimas administrācija būtu padota Ministru kabinetam, tas l̦autu Ministru kabinetam nepamatoti iejaukties Saeimas darbā.

Pastāv gan izṇēmums, un tas attiecas uz Tiesu administrāciju. Tiesu administrācija būtībā ir tiesu apkalpojošā iestāde, ko apliecina arī Tiesu administrācijas nolikumā minētais, ka šìs iestādes mērḳis ir nodrošināt atbalstu rajonu (pilsētu) tiesu, apgabaltiesu un zemesgrāmatu nodaļu efektīvam darbam un attīstībai. ${ }^{25}$ Tiesu administrācija, saskaņojot ar tiesas priekšsēdētāju, pieņem darbā un atlaiž no darba zemesgrāmatas un rajonu (pilsētu) tiesu un apgabaltiesu darbiniekus, izdod rīkojumus par darbinieku atval̦inājumiem, komandējumiem un apmācību. ${ }^{26}$ Taču Tiesu administrācija ir tiešās pārvaldes iestāde un atrodas Ministru kabineta pakḷautībā, ko īsteno ar tieslietu ministra starpniecību. ${ }^{27}$ Var diskutēt, vai šāda situācija ir atbilstoša varas dalǐšanas principam, bet nevar kategoriski atbildēt, ka tā nonāk pretrunā ar varas dalīšanas principu, jo šis princips nevis kategoriski nodala valsts varas, bet gan savstarpēji tās līdzsvaro.

Valsts varas orgāna apkalpojošās iestādes nav valsts varas orgāna struktūrvienības. Tās ir atsevišķas iestādes - tām ir savs vadītājs, personāls, telpas un nodrošināti vajadzīgie finanšu līdzekḷi, un tās var uzskatīt par iestādēm, pat ja normatīvajos aktos tās ir maldīgi nosauktas par struktūrvienībām. Nepieciešams vērtēt pēc būtības. Piemēram, likuma "Par tiesu varu" 50. ${ }^{1}$ panta pirmajā daḷā noteiktais, ka Augstākās tiesas administrācija ir Augstākās tiesas struktūrvienība, neliedz uzskatīt Augstākās tiesas administrāciju par iestādi, kas šobrīd padota tiesas priekšsēdētājam.

Satversmes 5. pants noteic, ka Saeima sastāv no 100 tautas priekšstāvjiem (deputātiem). Tātad ir pilnīgi skaidrs, ka Saeimas administrācija nav Saeimas sastāvā, jo Saeimas administrācijā strādā nevis deputāti, bet gan darbinieki. Tas pats ir ar Satversmes tiesas kanceleju - tās sastāvā ir darbinieki, nevis Satversmes tiesas tiesneši, un tāpēc tā nevar būt Satversmes tiesas sastāvā. Atbilstoši Satversmes tiesas likuma 3. pantam Satversmes tiesā ir septiṇi tiesneši. Turklāt kā Saeimas, tā Satversmes tiesas gadījumā, kad normatīvajos aktos ir minēta Saeima vai Satversmes tiesa, ar to saprot 100 deputātus vai septiņus Satversmes tiesas tiesnešus, nevis šo valsts varas orgānu apkalpojošās iestādes. Piemēram, Satversmes tiesas likuma 16. panta 1. punktā ir noteikts, ka Satversmes tiesa izskata lietas par likumu atbilstību Satversmei, un nav šaubu, ka ar vārdiem "Satversmes tiesa" ir domāti Satversmes tiesas tiesneši. Tāpat Satversmes 9. pants noteic, ka Saeimā var ievēlēt katru pilntiesīgu Latvijas pilsoni, kurš vēlēšanu pirmajā dienā ir vecāks par 21 gadu. Ir skaidrs, ka ar vārdu "Saeimā" šajā normā saprot nevis Saeimas apkalpojošo iestādi, bet gan Saeimas deputātu. Citādi būtu jāsecina, ka arī attiecībā uz Saeimas administrācijas darbinieku vietām būtu jārīko vēlēšanas, un administrācijā varētu strādāt tikai tie, kas vecāki par 21 gadu.

Attiecībā uz Augstākās tiesas administrāciju ir tas pats - tā nav Augstākās tiesas sastāvā. Augstākās tiesas administrācija nevar būt Augstākās tiesas sastāvā, jo tās sastāvā ir darbinieki, nevis tiesneši. Tiesas sastāv no tiesnešiem, un tas izriet no

\footnotetext{
25 Sk. Ministru kabineta 30.09.2014. noteikumu Nr. 589 “Tiesu administrācijas nolikums” 2. punktu.

26 Sk. likuma "Par tiesu varu" 107. ${ }^{1}$ panta otrās daḷas 8. punktu.

27 Sk. turpat, 1. punkts.
} 
Satversmes 82. panta vārdiem "tiesu Latvijā spriež", un tas tā līdz šim ir saprasts arī normatīvajos aktos, kur lietoti, piemēram, vārdi "pārsūdzēt Augstākajā tiesā". ${ }^{28}$ Nevar būt tā, ka ar vārdiem "Augstākā tiesa" vienā normatīvajā aktā saprot tikai Augstākās tiesas tiesnešus, bet citos - Augstāko tiesu un tās apkalpojošo iestādi. Tas būtu pretēji Satversmes 82. panta loğikai.

Attiecībā uz Valsts prezidentu, Valsts kanceleju un Tiesu administrāciju ir skaidrs, ka tās nav attiecīgi Valsts prezidenta, Ministru kabineta vai tiesas sastāvā. Likuma "Par Valsts prezidenta darbības nodrošināšanu" 5. panta pirmā daḷa konkrēti noteic, ka Valsts prezidenta kanceleja ir patstāvīga institūcija. Attiecībā uz Tiesu administrāciju un Valsts kanceleju tās nolikumā arī ir konkrēti norādīts šīs iestādes statuss - tiešās pārvaldes iestāde. ${ }^{29}$

Jāpiemin, ka sistēmiski nepareizi būtu viena valsts varas orgāna apkalpojošo institūciju atzīt par valsts varas orgāna struktūrvienību, bet cita orgāna apkalpojošo institūciju - par iestādi.

Nācies dzirdēt argumentu, ka valsts varas orgānu apkalpojošās iestādes ir struktūrvienības, jo tās atrodas vienā un tajā pašā èkā ar valsts varas orgānu. Tomēr šāda argumentācija neiztur kritiku. Tas vien, ka valsts varas orgāna apkalpojošās iestādes atrodas tajā pašā èkā ar valsts varas orgānu, ir saistīta ar praktisku nepieciešamību, lai valsts varas orgāna apkalpojošā iestāde spētu efektīvi pildìt tai uzticētās funkcijas. Tādẹl šis apstāklis nenozīmē, ka tās ir attiecīgā valsts varas orgāna struktūrvienības. Piemēram, neviens neapgalvos, ka Augstākā tiesa ir Tieslietu ministrijas struktūrvienība, Tieslietu ministrija ir Ministru kabineta struktūrvienība, vai arī Valsts kanceleja ir Ministru kabineta struktūrvienība, lai gan visas šîs institūcijas atrodas vienā un tajā pašà ēkā, īpaši tas attiecas uz Ministru kabinetu un Valsts kanceleju. Tāpat neviens negrasītos apgalvot, ka Pilsonības un migrācijas lietu pārvaldes Rīgas 2. nodaḷa bija Satversmes tiesas struktūrvienība (vai arī otrādi), lai arī tās abas savulaik atradās vienā un tajā pašā ēkā Jura Alunāna ielā 1, Rīgā.

Valsts varas orgāna apkalpojošās iestādes ir būtiski nošķirt no valsts pārvaldes iestādēm, kuras ir padotas Ministru kabinetam. Satversmes 58. pants noteic, ka valsts pārvaldes iestādes ir padotas Ministru kabinetam. Ar "valsts pārvaldes iestādi" Satversmes 58. pantā saprot ikvienu institūciju, kura pārsvarā pilda izpildvaras funkcijas, nevis līdzdarbojas tiesu spriešanas un likumdošanas funkciju ìstenošanā. ${ }^{30}$ Tā kā valsts varas orgāna apkalpojošās iestādes pārsvarā līdzdarbojas likumdošanas un tiesu spriešanas jomā, tās nav "valsts pārvaldes iestādes" Satversmes 58. panta izpratnē. ${ }^{31}$ Valsts varas orgānu apkalpojošo iestāžu atzī̌̌ana par valsts pārvaldes iestādēm neatbilstu arī Satversmes loǵikai, proti, Satversmes 58. pants nevar paredzēt, ka valsts varas orgānu iestādes ir padotas Ministru kabinetam, jo tas pārkāptu Satversmes 1. pantu, konkrētāk, varas dalīšanas principu. ${ }^{32}$ Izṇēmums ir tās apkalpojošās iestādes, kuras ir tiešās pārvaldes iestādes,

${ }_{28}$ Piemēram, sk. Kriminālprocesa likuma 560. panta trešo dal̦u, 705. ${ }^{1}$ panta otro dal̦u, 720. panta otro dal̦u, 760. panta septīto daḷu un Civilprocesa likuma 449. panta otro daḷu, 641. panta pirmo dal̦u un 651.6 panta pirmo dal̦.

${ }^{29}$ Sk. Ministru kabineta 30.09.2014. noteikumu Nr. 589 “Tiesu administrācijas nolikums” 1. punktu un Ministru kabineta 20.05.2003. noteikumu Nr. 263 "Valsts kancelejas nolikums" 1. punktu.

30 Sk.: Danovskis E., Briede J. 2017, 557. lpp.

31 Ibid.

32 Satversmes tiesa ir atzinusi: "Satversmes vienotības princips liedz atsevišķu konstitucionālo normu iztulkot atrauti no citām Satversmes normām, jo Satversme kā vienots dokuments ietekmē katras atsevišķas normas tvērumu un saturu." Par to sk. Satversmes tiesas 18.10.2007. sprieduma lietā Nr. 2007-03-01 30. punktu. 
proti, Valsts kanceleja un Tiesu administrācija. Attiecībā uz Valsts kanceleju tas ir logiski, ņemot vērā, ka Ministru kabinets īsteno izpildu varas funkcijas un tam padotās iestādes ir valsts pārvaldes iestādes, tātad arī tā apkalpojošā iestāde (Valsts kanceleja) ir valsts pārvaldes iestāde. Taču Valsts kancelejai ir arī savas patstāvīgās funkcijas, piemēram, nodrošināt valsts pārvaldes un cilvēkresursu attīstības politikas izstrādi, koordinēt un pārraudzīt tās ieviešanu. ${ }^{33}$ Tādēḷ Valsts kanceleja, no vienas puses, ir Ministru kabineta apkalpojošā iestāde, bet, no otras puses, iestāde ar patstāvīgām funkcijām.

Valsts varas orgāna iestādes nošķiramas no tā sauktajām patstāvīgajām iestādēm, proti, Centrālās vēlēšanu komisijas, Centrālās zemes komisijas, Sabiedrisko pakalpojumu regulēšanas komisijas, Latvijas Bankas, Finanšu un kapitāla tirgus komisijas, Nacionālās elektronisko plašsaziņas līdzekḷu padomes un Tiesībsarga biroja. Šìs iestādes ir "valsts pārvaldes iestādes" Satversmes 58. panta izpratnē, tomēr noteiktu iemeslu dēl tās ir izņemtas no padotības Ministru kabinetam, un to darbību uzrauga Saeima. Valsts varas orgāna apkalpojošo iestāžu nošķiršana no tā sauktajām patstāvīgajām iestādēm ir svarīga, jo būtiski atšķiras šo iestāžu funkcijas un pastāvēšanas jēga, un valsts varas orgānu apkalpojošās iestādes nav patstāvīgas - tās ir padotas attiecīgajam valsts varas orgānam.

Valsts varas orgāna apkalpojošās iestādes darbinieku padotība var atškirirties darbinieku starpā. Var būt noteikts, ka viena veida darbinieki ir padoti, piemēram, orgāna apkalpojošās iestādes vadītājam, kamēr citi darbinieki - pašam valsts varas orgānam. Piemēram, Valsts prezidenta kancelejas vadītājs, Valsts prezidenta kancelejas vadītāja vietnieks un Valsts prezidenta padomnieki ir tieši pakḷauti Valsts prezidentam un Valsts prezidenta kancelejas vadītājam. ${ }^{34}$ Tas, vai valsts varas orgānam ir nepieciešams padotību îstenot pašam vai ar apkalpojošās iestādes starpniecību, ir lietderības jautājums.

\section{Valsts varas orgānu apkalpojošo iestāžu regulējums un praktiskie jautājumi}

Valsts varas orgānu apkalpojošās iestādes regulē gan ārējie, gan iekšèjie normatīvie akti. Pamatā valsts varas orgānu apkalpojošo iestāžu regulējums ir ietverts šādos normatīvajos aktos:

- Saeimas kārtības rullī (Saeimas administrācija);

- likumā "Par valsts prezidenta darbības nodrošināšanu" (Valsts prezidenta kanceleja);

- Ministru kabineta iekārtas likumā un Ministru kabineta kārtības rullī (Valsts kanceleja);

- likumā "Par tiesu varu” (Augstākās tiesas administrācija un Tiesu administrācija);

- Satversmes tiesas reglamentā (Satversmes tiesas kanceleja);

- Valsts pārvaldes iekārtas likumā;

- iestāžu nolikumos (piemēram, Saeimas administrācijas, Valsts prezidenta kancelejas, Valsts kancelejas un Tiesu administrācijas nolikums).

${ }^{33}$ Sk. Ministru kabineta 20.05.2003. noteikumu Nr. 263 "Valsts kancelejas nolikums" 3.4. punktu.

${ }^{34}$ Sk. likuma "Par Valsts prezidenta darbības nodrošināšanu" 6. panta pirmo daļu un Valsts prezidenta kancelejas nolikuma 17. punktu. Pieejams: https://www.president.lv/lv/kontakti/valsts-prezidentakanceleja/nolikums [aplūkots 13.01.2019.]. 
Attiecībā uz tādām apkalpojošām iestādēm, kas ir valsts pārvaldes iestādes, piemērojams Valsts pārvaldes iekārtas likums. Savukārt attiecībā uz citām valsts varas orgānu apkalpojošām iestādēm Valsts pārvaldes iekārtas likums ir piemērojams, ciktāl citu likumu speciālajās normās nav noteikts citādi. ${ }^{35}$ Tas nepieprasa, lai citos likumos būtu konkrēti izslēgta noteiktu Valsts pārvaldes iekārtas likuma normu piemērojamība, bet gan pieprasa vērtēt to, ciktāl uz valsts varas orgānu apkalpojošām iestādēm, ņemot vērā šo iestāžu īpašo statusu, ir piemērojams Valsts pārvaldes iekārtas likums.

Ja ne visus, vismaz lielāko daḷu Valsts pārvaldes iekārtas likuma principu var piemērot valsts varas orgānu apkalpojošām iestādēm, piemēram, to, ka šì iestāde ir pakḷauta likumam un tiesībām, tā darbojas normativajos aktos noteiktās kompetences ietvaros un var izmantot savas pilnvaras tikai atbilstoši pilnvarojuma jēgai un mērķim, tā savā darbībā ievēro cilvēktiesības un darbojas sabiedrības interesēs, tai nav savu interešu, īstenojot tai noteiktās funkcijas, un tā informē sabiedrību par valsts varas orgāna darbību. ${ }^{36}$ Tāpat attiecībā uz Valsts prezidenta kanceleju likuma "Par Valsts prezidenta darbības nodrošināšanu" 5. panta piektajā daḷā ir noteikts, ka Valsts prezidenta kanceleja iekšējos normatīvos aktus izdod, pamatojoties uz Valsts pārvaldes iekārtas likumu. Taču tas nav noteikts visu valsts varas orgānu apkalpojošo iestāžu regulējošos normatīvos aktos. Nav skaidrs, vai ir iespējams piemērot Valsts pārvaldes iekārtas likuma normas par pārvaldes lēmuma pārbaudi un atbildību par to, normas par sadarbības, līdzdarbības un administratīvo lïgumu.

Valsts varas orgānu apkalpojošās iestādes darbojas Latvijas Republikas vārdā. Tāpēc lietās, kurās ir apstrīdēti šo orgānu apkalpojošo iestāžu administratīvie akti vai faktiskā rīcība, atbildētājs tiesā ir Latvijas Republika kā sākotnējā publisko tiesību juridiskā persona. Apkalpojošām iestādēm nepiemìt tiesībspējas, jo tās nav juridiskās personas. ${ }^{37}$ Piemēram, ja Saeimas administrācija atsakās atbildēt uz iesniegumu, tad, pārsūdzot šādu neatbildēšanu tiesā, atbildētājs tiesā būs Latvijas Republika kā sākotnējā publisko tiesību juridiskā persona, nevis tās valsts varas orgāns - Saeima - vai arī Saeimas administrācija kā Saeimas apkalpojošā iestāde.

Nepastāv noteiktība jautājumā par administratīvo aktu un faktiskās rīcības apstrīdēšanu. Saeimas kārtības rullī ir noteikts, ka Saeimas administrācijas administratìvos aktus un faktisko rīcību var apstrīdēt Saeimas prezidijā Administratīiā procesa likumā noteiktajā kārtībā. ${ }^{38}$ Attiecībā uz Tiesu administrācijas un Valsts kancelejas administratīvajiem aktiem vai faktisko rīcību ir skaidrs, ka tos var apstrīdēt padotības kārtībā augstākā iestādē, jo šìs iestādes ir tiešās pārvaldes iestādes. Tomēr attiecībā uz Valsts prezidenta kanceleju, Satversmes tiesas kanceleju vai Augstākās tiesas administrāciju to darbību regulējošos ārējos normatīvajos aktos nav noteikts, kas var apstrīdēt to administratīvos aktus vai faktisko rīcību, piemēram, vai tas ir Valsts prezidents, Augstākās tiesas priekšsēdētājs vai plēnums, vai arī Satversmes tiesas priekšsēdētājs vai visi tiesneši kopā. Likuma "Par tiesu varu"

\footnotetext{
35 Valsts pārvaldes iekārtas likuma 3. panta trešā daḷa noteic: "Valsts pārvaldes principi un citi šā likuma noteikumi attiecināmi arī uz iestādēm, kuras nav padotas Ministru kabinetam, ciktāl citu likumu speciālajās tiesību normās nav noteikts citādi." Tomēr ir nepieciešams izvērtēt, ciktāl pēc būtības ir iespējams attiecināt šā likuma normas uz apkalpojošām iestādēm.

${ }^{36}$ Plašāk par šiem principiem sk. Valsts pārvaldes iekārtas likuma 10. pantu.

37 Plašāk par to sk.: Danovskis E., Briede J. Publisko tiesību subjektu civiltiesiskais statuss. Jurista Vārds, 14.02.2012., Nr. 7 (706), 6.-11. lpp.

38 Sk. Saeimas kārtības rullıa 23. ${ }^{1}$ pantu.
} 
$28 .^{5}$ panta pirmā daḷa noteic, ka tiesas atteikumu izsniegt pieprasīto informāciju Administratīvā procesa likumā noteiktajā kārtībā var apstrīdēt Tieslietu ministrijā, pēc tam - tiesā.

Nav vienotības arī jautājumā par darba tiesisko attiecību nodibināšanu ar valsts varas orgānu apkalpojošo orgānu darbiniekiem. Atbilstoši Satversmes tiesas reglamenta 31. panta 3. punktam Satversmes tiesas priekšsēdētājs pieñem darbā un atlaiž no darba Satversmes tiesas darbiniekus. Valsts prezidenta kancelejas gadijumā likuma "Par Valsts prezidenta darbības nodrošināšanu" 6. panta pirmā daḷa noteic, ka kanceleju vada Valsts prezidenta iecelts vadītājs, tātad var secināt, ka Valsts prezidents slēdz arī darba līgumus ar kancelejas vadītāju. Likuma "Par tiesu varu" $50 .^{1}$ panta otrā daḷa noteic, ka administrācijas vadītāju pieṇem darbā un atbrīvo no darba Augstākās tiesas priekšsēdētājs. Mazliet citādi ir Saeimas gadījumā. Piemēram, atbilstoši Saeimas kārtības rullim Saeimas prezidijs nodibina darba attiecības ar Saeimas administrācijas generālsekretāru un tās struktūrvienību vadītājiem. ${ }^{39}$ Darba tiesiskās attiecības ar frakcijas un komisijas darbiniekiem nodibina Saeimas administrācijas generālsekretārs. ${ }^{40}$ Ciktāl nav noteikts citādi, attiecībā uz valsts varas orgānu apkalpojošo iestāžu darbinieku pieņemšanu darbā var piemērot Valsts pārvaldes iekārtas likuma 17. panta otrās daḷas 4. punktu, saskaṇā ar to iestādes vadītājs pieṇem darbā un atlaiž darbiniekus.

Tas, ka valsts varas orgānu apkalpojošās iestādes ir uzskatāmas par iestādēm, nevis par valsts varas orgāna struktūrvienībām, ir svarīgi likuma "Par interešu konflikta novēršanu valsts amatpersonu darbībā” kontekstā. Šis likums noteic, ka publiskas personas institūcijas vadītājs cita starpā ir publiskas personas iestādes vadītājs, un likumā ir ietverti konkrēti uz iestādes vadītāju attiecināmi pienākumi, piemēram, atbilstoši savai kompetencei nepiel̦aut, ka institūcijā strādājošās valsts amatpersonas nonāktu interešu konflikta situācijā, ${ }^{41}$ izlemt jautājumu par valsts amatpersonas amata savienošanu ar citu amatu, uzṇēmuma līguma vai pilnvarojuma izpildi, ${ }^{42}$ nodrošināt valsts amatpersonu saraksta iesniegšanu Valsts ieņēmumu dienestam ${ }^{43}$ un nekavējoties informēt Korupcijas novēršanas un apkarošanas biroju par attiecīgā likuma pārkāpumiem. ${ }^{44}$ Tāpat tas ir svarīgi Publiskas personas finanšu līdzekḷu un mantas izšḳērdēšanas novēršanas likuma sakarā, ievērojot, ka šis likums noteic vairākus ierobežojumus, piemēram, aizliegumu iek,īlāt valsts iestāžu valdījumā esošu mantu ${ }^{45}$ vai atsavināt publiskas personas mantu privātpersonai vai kapitālsabiedrībai par acīmredzami pazeminātu cenu. ${ }^{46}$ Praksē ir svarīgi saprast, vai šie pienākumi attiecas uz apkalpojošās iestādes vadītāju, valsts varas orgānu vai uz kādu orgāna organizatorisko veidojumu.

Ne visām valsts varas orgānu apkalpojošām iestādēm ir pievienotās vērtības nodokḷa reǵistrācijas numurs, ne visas ir reǵistrētas Publisko personu un to iestāžu reǵistrā, un ne visām ir arī atsevišķa pozīcija ikgadējā valsts budžeta likumā,

\footnotetext{
39 Sk. Saeimas kārtības ruḷla 23. panta pirmās daḷas 2. punktu.

40 Sk. Saeimas kārtības ruḷ̦a 182. pantu un 187. panta pirmo dal̦u.

${ }^{41}$ Sk. likuma "Par interešu konflikta novēršanu valsts amatpersonu darbībā" 20. panta pirmo dal̦u.

42 Sk. ibid., 20. panta otro dal̦u.

43 Sk. ibid., 20. panta trešo dal̦u.

44 Sk. ibid., 20. panta sesto dal̦u.

${ }^{4}$ Sk. Publiskas personas finanšu līdzekḷu un mantas izšķērdēšanas novēršanas likuma 9. panta pirmo dalı.

46 Sk. ibid., 7. panta pirmo dal̦u.
} 
pieškirot valsts budžeta līdzekḷus. Tomēr šie nav leǵitīmi iemesli, kāpēc valsts varas orgānu apkalpojošās iestādes būtu jāuzskata par struktūrvienībām.

Publisko personu un to iestāžu reg̣istra izveidošana ir saistīta ar Oficiālās elektroniskās adreses likumu, kurš ievieš obligātu oficiālās elektroniskās adreses izmantošanu valsts iestādēs. ${ }^{47}$ Registrācijas mērḳis bija nevis atzìt, kas ir iestāde, bet gan saprast, kam ir nepieciešama oficiālā elektroniskā adrese. Tāpēc no tā, ka noteikta institūcija ir vai nav ietverta reǵistrā, nevar secināt, vai šì institūcija ir vai nav iestāde. Iestāde savu statusu iegūst ar nodibināšanas brīdi, nevis ietveršanu kādā reǵistrā. Piemēram, Publisko personu un to iestāžu reǵistrā ir reǵistrēta Valsts prezidenta kanceleja kā Valsts prezidenta apkalpojošā iestāde, bet nav registrētas tādas valsts varas orgānu apkalpojošās iestādes kā Saeimas administrācija vai Satversmes tiesas kanceleja. ${ }^{48}$ Tāpat Publisko personu un to iestāžu reǵistrā nav ietverts Ministru kabinets, bet ir Saeima. Tam, kāpēc Publisko personu un to iestāžu reǵistrā ir ietverta Valsts prezidenta kanceleja, bet nav Saeimas administrācija (iestādes), vai arī ir ietverta Saeima, bet nav Ministru kabinets (valsts varas orgāni), nav juridiska izskaidrojuma.

Tas, kā notiek valsts budžeta līdzekḷu piešķiršana valsts institūcijām, ir lietderības jautājums, un no tā nevar izdarìt secinājumu, vai kāda institūcija ir iestāde vai struktūrvienība. Atsevišķas budžeta pozīcijas ir gan valsts varas orgānu apkalpojošām iestādēm (Valsts prezidenta kancelejai), gan valsts varas orgāniem (Saeimai, Ministru kabinetam, Satversmes tiesai un Valsts kontrolei), gan tiesu varas institūcijai (prokuratūrai), gan arī pārvaldes institūcijām (Aizsardzības ministrijai, Tieslietu ministrijai utt.). Nav juridiska izskaidrojuma, kāpēc atsevišķa budžeta pozīcija ikgadējā valsts budžeta likumā ir piešksirta Valsts prezidenta kancelejai, bet nav piešksirta citu valsts varas orgānu apkalpojošām iestādēm, vai arī kāpēc Augstākā tiesa budžeta līdzekḷu piešḳiršanas ziṇā ir atsevišḳi izdalīta no citām tiesām. ${ }^{49}$ Turklāt Valsts prezidenta kanceleja šajā sakarā būtu izceḷama kā izṇēmums. Logiski būtu, ja valsts varas orgānu apkalpojošām iestādēm nebūtu atsevišķas budžeta pozīcijas, bet to budžets būtu ierēḳināts valsts varas orgāna budžetā, jo valsts budžeta līdzekḷi ir vajadzīgi valsts varas orgānam un apkalpojošā iestāde tikai palīdz valsts varas orgānam īstenot tā funkcijas. Taču tas ir lietderības, ne juridisks jautājums.

Nācies dzirdēt argumentu, ka valsts varas orgānu apkalpojošās iestādes nevar atzìt par iestādēm un ka tās arī turpmāk jāuzskata par valsts varas orgānu struktūrvienībām, īpaši Augstākās tiesas gadījumā, jo tad valsts varas orgāns nevarētu pieprasìt nepieciešamo budžetu valsts varas orgāna apkalpojošās iestādes darbībai. Šāds arguments ir maldinošs. Valsts varas orgāna apkalpojošā iestāde, ja tā patiesi vajadzīga valsts varas orgānam, lai īstenotu savas funkcijas, nevar palikt bez finanšu līdzekḷiem, un tā tam jābūt tik ilgi, kamēr pastāv valsts varas orgāns. Piemēram, neatkarīgi no Saeimas administrācijas, Valsts kancelejas, Satversmes tiesas kancelejas vai Augstākās tiesas administrācijas statusa ir skaidrs, ka tām ir nepieciešams piešķirt valsts budžeta līdzekḷus, jo citādi attiecīgais valsts varas orgāns vai vismaz daḷa no tā (Augstākā tiesa) nespēs pilnvērtīgi funkcionēt, un

\footnotetext{
47 Sk. Oficiālās elektroniskās adreses likuma 5. panta pirmo daḷu.

48 To, kas ir reǵistrēts Publisko personu un iestāžu reǵistrā, var redzēt Uzṇēmumu reǵistra tīmekḷivietnē, ievadot attiecīgās institūcijas nosaukumu: https://www.ur.gov.lv/lv. Sk. arī likuma "Par Latvijas Republikas Uzṇēmumu reǵistru” $18 \cdot{ }^{17}$ pantu.

49 Piemēram, sk. likumprojektam Nr. 1068/Lp12 "Par budžetu 2018. gadam” pievienotos paskaidrojumus. Pieejams: www.saeima.lv [aplūkots 13.01.2019.].
} 
tas pārkāptu Satversmi, piemēram, tiesu gadījumā - tiesu varas neatkarības principu. Turklāt tas, ka attiecīgā valsts varas orgāns budžeta pozīcijā tiks ietverts arī budžets savai apkalpojošai iestādei, ja iestādei pašai nav atsevišķa budžeta pozīcija (tas ir Valsts prezidenta kancelejas gadijums), ir pašsaprotams, ņemot vērā, ka tā ir tieši valsts varas orgāna apkalpojošā iestāde. ${ }^{50}$ Piemēram, ir pašsaprotams, ka Satversmes tiesas budžeta pozīcijā būs ietverts nepieciešamais budžets Satversmes tiesas kancelejai, Saeimas budžeta pozīcijā - Saeimas administrācijai, bet Augstākās tiesas budžeta pozīcijā - Augstākās tiesas administrācijai, un tā tas ir arī bijis, piemēram, pieṇemot likumu "Par valsts budžetu 2018. gadam". ${ }^{51}$

\section{Kopsavilkums}

1. Valsts varas orgāniem ir savas apkalpojošās iestādes. Šo iestāžu mērḳis ir nodrošināt attiecīgo valsts varas orgānu darbību, palīdzot tiem ìstenot to funkcijas Satversmes robežās un risinot dažādus administratīva rakstura jautājumus (apkalpojošā funkcija). Valsts varas orgāna apkalpojošās iestādes pastāvēšana ir attaisnojama ar paša valsts varas orgāna esību.

2. Ir šādas valsts varas orgānu apkalpojošās iestādes: Saeimas administrācija Saeimai, Valsts prezidenta kanceleja - Valsts prezidentam, Valsts kanceleja - Ministru kabinetam, Augstākās tiesas administrācija un Tiesu administrācija - tiesām, Satversmes tiesas kanceleja - Satversmes tiesai.

3. Valsts varas orgāna apkalpojošās iestādes izveidošanai nav nepieciešams likums. To var izveidot arī pats valsts varas orgāns, pieņemot attiecīgu lēmumu. Valsts varas orgāna apkalpojošā iestāde var būt padota tikai tam valsts varas orgānam, kuram šì iestāde palīdz īstenot tā funkcijas. Izṇēmumi no šā principa tulkojami šauri, un šāds izņēmums ir Tiesu administrācija.

4. Valsts varas orgāns pats var noteikt savas apkalpojošās iestādes kompetenci. Valsts varas orgāna apkalpojošās iestādes darbības regulējums var būt ietverts iekšējos normativijos aktos.

5. Valsts varas orgānu apkalpojošās iestādes neietilpst šo orgānu sastāvā. Tās ir atsevišķas valsts iestādes, kuras statusu iegūst ar izveidošanas brīdi. Šādu iestāžu atrašanās vienā ēkā (telpā) ar valsts varas orgānu izriet no praktiskas nepieciešamības.

6. Uz valsts varas orgānu apkalpojošām iestādēm, ciktāl likums nenoteic citādi un tas ir iespējams pēc būtības, ir piemērojams Valsts pārvaldes iekārtas likums, Publiskas personas finanšu līdzekḷu un mantas izškzeērdēšanas novēršanas likums un citi likumi.

7. Turpmāk normatīvajos aktos, lai apzīmētu valsts varas orgānu apkalpojošās iestādes, ieteicams lietot jēdzienu "iestāde", nevis "struktūrvienība", arī Augstākās tiesas administrācijas gadījumā. Pat ja normatīvajos aktos valsts varas orgāna apkalpojošā iestāde maldīgi nosaukta par struktūrvienību, to var uzskatìt par iestādi.

${ }^{50}$ Ir izṇēmumi, piemēram, Valsts prezidenta kancelejai ir sava budžeta pozīcija (nevis Valsts prezidentam). Tāpat budžetu rajona (pilsētas) tiesām un apgabaltiesām pieprasa Tieslietu ministrija.

51 Sk. likumprojektam Nr. 1068/Lp12 "Par budžetu 2018. gadam” pievienotos paskaidrojumus. Pieejams: www.saeima.lv [aplūkots 13.01.2019.]. 